\title{
SUPERVISI PENDIDIKAN UNTUK MENINGKATKAN \\ KUALITAS PEMBELAJARAN DI INDONESIA
}

\author{
Oleh : Lialy Sarti \\ Universitas Negeri Padang \\ E-mail : lialysarti1710@gmail.com
}

\begin{abstract}
Mutu pendidikan di Indonesia masih rendah dibandingkan dengan negara lain. Hal ini disebabkan oleh proses pembelajaran yang kurang melibatkan peserta didik. Sehingga, peserta didik menjadi tidak kreatif dalam membangun pengetahuan dan mengemukakan ise atau gagasannya. Oleh karena itu, supervisi pendidikan memiliki peran yang sangat penting untuk menciptakan suasana belajar yang mengembangkan potensi yang dimiliki peserta didik. Supervisi pendidikan memiliki makna kerja sama antara guru dan supervisor pendidikan dalam meningkatkan kualitas pembelajaran. Proses pembelajaran berpusat kepada peserta didik. Selain itu, guru dan bekerja sama dalam memilih dan menetapkan strategi/metode/pendekatan/teknik pembelajaran serta model pembelajaran yang tepat agar proses pembelajaran bermakna. Dengan begitu, supervise pendidikan penting untuk meningkatkan kualitas pembelajaran.
\end{abstract}

Kata Kunci : Supervisi pendidikan, meningkatkan kualitas pembelajaran

\section{PENDAHULUAN}

Menurut Kepala Badan Penelitian dan Pengembangan Kementerian Pendidikan dan Kebudayaan (Kemendikbud), Totok Suprayitno, mengatakan bahwa,'Dari tahun ke tahun, peringkat PISA (Programme for International Student Assesment) untuk Indonesia tidak mengalami peningkatan yang signifikan. Hal ini disebabkan karena kualitas pendidikan yang tidak mengalami peningkatan yang berarti. Proses pembelajaran akan bermuara pada peningkatan kualitas penididikan di Indonesia." Proses pembelajaran yang banyak dilakukan oleh guru di Indonesia, masih cenderung pada penguasaan materi yang dituntut oleh kurikulum dan lebih mementingkan penghafalan konsep. Guru cenderung hanya menyampaikan materi dengan menggunakan metode ceramah dalam proses pembelajarannya tanpa melibatkan keaktifan peserta didknya atau bisa dikatakan proses pembelajaran hanya berpusat pada guru. Sehingga peserta didik merasa proses pembelajaran terkesan monoton, karena peserta didik hanya duduk, mencatat, dan mendengarkan apa yang dijelaskan atau disampaikan oleh gurunya. Oleh karena itu, kreativitas dan kemandirian peserta didik dalam menemukan dan membangun pengetahuannya sendiri menjadi 
ttidak tersalurkan. Tidak hanya itu, peserta didik juga tidak mampu menyelesaikan masalah yang kompleks, karena guru hanya memberikan materi yang tidak bersifat detail atau guru tidak menjabarkan materi secara luas dan mendalam. Sehingga siswa tidak mampu berpikir kritis dalam menyelesaikan masalah yang dihadapinya. Selain itu, juga banyak kasus yang sangat miris tentang pendidikan di Indonesia dimana peserta didik tega menganiaya gurunya sendiri. Sehingga, dapat kita lihat bahwa proses pembelajaran masih kurang memperhatikan aspek sikap atau karakter peserta didik. Tidak heran pendidikan di Indonesia hanya memetingkan aspek kognitif atau pengetahuan yang dimilikinya dan bahkan terkesan guru hanya menilai hasil tanpa mengindahkan proses yang dilalui peserta didik.

Padahal, menurut Undang-Undang No. 20 Tahun 2003 tentang SISDIKNAS, pendidikan adalah usaha sadar dan terencana untuk mewujudkan suasana belajar dan proses pembelajaran agar peserta didik secara aktif mengembangkan potensi dirinya untuk memiliki kekuatan spiritual keagamaan, pengendalian diri, kepribadian, kecerdasan, akhlak mulia, serta keterampilan yang diperlukan dirinya, masyarakat, bangsa dan negara. Jadi, hal yang pertama sekali yang ingin diwujudkan oleh pendidikan adalah suasana belajar dan proses pembelajaran agar peserta didik secara aktif mengembangkan potensi yang dimilikinya. Menurut Peraturan Pemerintah No. 19 Tahun 2005 Tentang Standar Nasional Pendidikan pada pasal 19 ayat 1 mengatakan bahwa, "Proses pembelajaran pada satuan pendidikan diselenggarakan secara interaktif, inspiratif, menyenangkan, menantang, memotivasi peserta didik untuk berpartisipasi aktif, serta memberikan ruang yang cukup bagi prakarsa, kreativitas, dan kemandirian sesuai dengan bakat, minat, dan perkembangan fisik serta psikologis peserta didik."

Berdasarkan uraian diatas maka permasalahan dalam tulisan ini adalah (1) Apa tindakan yang dilakukan guru dan supervisor pendidikan untuk meningkatkan kualitas pembelajaran? Tujuan dalam tulisan ini adalah (1) Untuk menjelaskan tindakan yang dilakukan oleh guru dan supervisor pendidikan untuk meningkatkan kualitas pembelajaran. Sehingga peserta didik menjadi kreatif, inovatif, terampil, dan mampu berpikir kritis terhadap fenomena atau masalah yang dihadapinya dan memiliki karakter, kepribadian, dan akhlak mulia serta pengendalian diri.

\section{PEMBAHASAN}

Untuk meningkatkan kualitas pembelajaran atau dalam hal ini menciptakan suasana pembelajaran yang inspiratif, interaktif, dan menyenangkan, guru harus mampu menggunakan teknik pembelajaran, metode pembelajaran, strategi pembelajaran, dan pendekatan pembelajaran serta model pembelajaran yang tepat dalam proses pembelajaran. Guru juga tidak terkaku dalam menyampaikan dan menjelaskan materi kepada siswa, melainkan guru juga melibatkan peserta didik dalam proses pembelajaran. Guru memotivasi dan menstimulus peserta didik untuk aktif mengemukakan pengetahuan, ide, dan gagasan yang dimilikinya dalam proses pembelajaran. Proses pembelajaran berpusat pada peserta didik (student-centered). Oleh 
karena itu, guru bisa menerapkan model pembelajaran konstruktivisme dan kooperatif. Dimana pada model pembelajaran konstruktivisme, peserta didik membangun dan menemukan pengetahuannya sendiri dan guru berperan sebagai fasilitator. Sedangkan pada model pembelajaran kooperatif, guru bisa menerapkan diskusi kelompok pada proses pembelajaran. Dengan begitu, peserta didik mampu bekerja sama dengan sesama temannya dan memiliki sikap peduli dan mau membantu temannya yang kesulitan dalam memahami materi pelajaran. Begitu juga dengan metode guru dalam mengajar, guru tidak hanya menggunakan metode ceramah dalam menyampaikan materi. Guru bisa menggunakan metode discovery, diskusi, inquiry, atau metode lainnya sehingga siswa merasa senang dalam belajar sekaligus mudah memeahami materi pelajaran. Itulah beberapa hal pening yang harus diperhatikan guru dalam menciptakan lingkungan belajar yang kondusif untuk siswa.

Suryani (2015:28) mengatakan bahwa kemampuan guru dalam proses belajar mengajar guru di sekolah adalah penguasaan materi atau bahan, metode, alat dan evaluasi. Guru sebagai pendidik tidak hanya berkenaan dengan penyampaian ilmu pengetahuan tetapi juga juga menyangkut pengembangan kepribadian dan pembentukan nilai-nilai etika dan estetika para siswa dalam menghadapi tantangan hidup masyarakat. Tidak hanya guru yang memiliki tanggung jawab terhadap pendidikan melainkan juga supervisor. Supervisor mengawasi, mengontrol, memimpin, atau membina sumber daya manusia yang meliputi perencanaan, pengamatan, pengawasan, dan pembinaan. Dimana, dalam menata sumber daya manusia, supervisor memerlukan sebuah pengontrolan yang mencakup kunjungan kelas, observasi kelas, wawancara indiviru, saling mengunjungi, evaluasi diri, dan lain-lain. Tidak hanya itu, supervisi juga membantu guru-guru dalam menciptakan kondisi belajar yang baik, memonitori guruguru agar berbuat sebagaimana mestinya, mencari sebab sebuah kesalahan, memberi saran, dan membimbing. Oleh karena itu, supervisor tidak hanya mencari kesalahankesalahan guru, tetapi juga berusaha mengadakan preventif agar guru melakukan apa yang semestinya. Supervisor memberikan bantuan teknis dan bimbingan kepada guru agar mampu meningkatkan kualitas kerjanya, terutama melaksanakan proses pembelajaran. Supervisor sungguhsungguh membantu guru agar dapat melakukan kerja yang lebih baik, terarah, dan sebagaimana mestinya.

Sabandi (2013:2) mengatakan bahwa supervisor memegang peranan penting dalam meningkatkan kualitas guru agar dapat melaksanakan pembelajaran yang lebih berkualitas dan bermakna. Dengan begitu, peserta didik juga akan memberikan prestasi yang baik di bidang akademik dan nonakademik.

Menurut Permendiknas Nomor 13 Tahun 2007 tentang Standar Kepala Sekolah/Madrasah, dimensi kompetensi kepala sekolah yang meliputi : (1) kompetensi kepribadian, (2) kompetensi manajerial, (3) kompetensi kewirausahaan, (4) kompetensi supervisi, dan (5) kompetensi sosial. kompetensi supervisi kepala sekolah terdiri atas 3 yaitu (1) merencanakan 
supervisi akademik, (2) melaksanakan supervisi akademik, dan (3) menindaklanjuti hasil supervisi akademik. Selain itu, pengawas juga memiliki tanggung jawab terhadap peningkatan kualitas dan mutu pendidikan di Indonesia. Menurut Permendiknas Nomor 12 Tahun 2007 tentang Standar Pengawas Sekolah/Madrasah, dimensi kompetensi pengawas sekolah/madrasah meliputi : (1) kompetensi kepribadian, (2) kompetensi supervisi manajerial, (3) kompetensi supervisi akademik, (4) kompetensi evaluasi pendidikan, (5) kompetensi penelitian pengembangan, dan (6) kompetensi sosial. Setiap kompetensi tersebut harus dimiliki oleh pengawas baik di jenjang TK, SD, SMP/MTs dan SMA/MA. Di dalam kompetensi supervisi manajerial, kompetensi yang harus dimiliki pengawas, antara lain menguasai metode, teknik, dan prinsipprinsip supervisi; menyusun program kepengawasan; menyusun metode kerja dan instrument; menyusun laporan hasil pengawasan; membina kepala skeolah; mendorong guru dan kepala sekolah dalam merefleksikan hasil yang dicapainya; dan memantau pelaksanaan standar nasional pendidikan. Sedangkan di dalam kompetensi supervise akademik, kompetensi yang harus dimiliki oleh pengawas adalah memahami konsep, prinsip, teori dasar, karakteristik, dan kecenderungan perkembangan tiap mata pelajaran; memahami konsep, prinsip teori/teknologi, karakteristik, dan kecenderungan perkembangan proses pembelajaran; membimbing guru dalam menyusun silabus; membimbing guru dalam memilih dan menggunakan strategi/metode/teknik pembelajaran; membimbing guru dalam menyusun RPP; membimbing guru dalam melaksanakan kegiatan pembelajaran; membimbing guru dalam mengelola, merawat, mengembangkan dan menggunakan media pendidikan dan fasilitas pembelajaran; dan memotivasi guru. Oleh karena itu, kepala sekolah dan pengawas sekolah/madrasah memiliki tanggung jawab dalam meningkatkan profesionalitas guru. Supervisi pendidikan memiliki makna kerja sama antara guru dengan pengawas dan kepala sekolah dengan tujuan mencapai tujuan pendidikan dan meningkatkan mutu pendidikan Indonesia. Bahkan dalam menentukan strategi/ teknik/metode/pendekatan pembelajaran dan model pembelajaran serta menyusun RPP, tidak hanya guru yang bertanggung jawab, melainkan juga supervisor pendidikan. Jadi, guru dan supervisor pendidikan memiliki peranan penting dalam meningkatkan kualitas pembelajaran di Indonesia.

\section{PENUTUP}

Berdasarkan uraian di atas, disimpulkan bahwa guru dan supervisor memiliki peranan penting dalam meningkatkan kualitas pembelajaran dan mutu pendidikan Indonesia. Guru dan supervisor harus mampu bekerja sama dalam mengembangkan kualitas pembelajaran. Sehingga peserta didik mampu mengembangkan potensi yang dimilikinya. Dengan terciptanya lingkungan yang kondusif untuk belajar, siswa merasa senang dan menjadi kreatif, inovatif, aktif, dan mampu berkerja sama serta memiliki karakter, kepribadian, dan berakhlak mulia. 


\section{DAFTAR PUSTAKA}

Sabandi, Ahmad. 2013. "Supervisi Pendidikan Untuk Pengembangan Profesionalitas Guru Berkelanjutan”. Ilmiah Ilmu Pendidikan Vol. XIII No.2.

Suryani, Cut. 2015. "Implementasi Supervisi Pendidikan dalam Meningkatkan Proses Pembelajaran di MIN Sukadamai Kota Banda Aceh". Ilmiah DIDAKTIKA Vol XVI No. 1. 